ECOLOGICA, Vol. 28, No 101 (2021), 99-104

https://doi.org/10.18485/ecologica.2021.28.101.15

Originalni naučni rad

UDC:616-036.21:330.34

\title{
Uticaj pandemije na ekonomski razvoj - tercijalne delatnosti
}

\section{The impact of the pandemic on economic development - tertiary activities}

\author{
Dragan Živković ${ }^{1}$, Pero Petrović ${ }^{2}$ Mašan Ercegović3 \\ ${ }^{1}$ Hotel Mažestik, Obilićev venac 28, Beograd, Srbija / Hotel Majestic, Obilicev venac 28, Belgrade, Serbia \\ ${ }^{2}$ Institut za međunarodnu politiku i privredu, Beograd / Institute of International Politics and Economics, Belgrade \\ ${ }^{3} \mathrm{MB}$ Univerzitet, Beograd / MB University, Belgrade
}

Rad primljen: 26.01.2021, Rad prihvaćen: 20.02.2021.

Sažetak: Ovaj rad objašnjava niz negativnih uticaja koji su uzrokovani pojavom krize poslovanja kao poledicom pandemije. U opštoj privrednoj krizi preduzećima i pojedincima (naročito iz uslužnih odnosno tercijalnih delatnosti) je neophodna pomoć u prevazilaženju teškoća koje izaziva dugoročna recesija, međutim takva pomoć ima svoje granice koje određuje fiskalni deficit i javni dug. Stoga, ako se te granice pređu, cela privreda biva izložena velikom riziku i makroekonomskoj nestabilnosti, koja bi pogodila sve segmente privrede i društva. Naravno, da to ima niz negativnih posledica naročito na uslužne delatnosti, posebno na turizam. Pandemija virusa korona od koje posrću privrede širom sveta samo je produbila socijalnu nejednakost. Dok jedan broj zaposlenih ima sreću da radi od kuće, milioni radnika ostaju bez posla ili rizikuju svoje zdravlje na slabije plaćenim poslovima, van domova. Međutim, 2020 godina ma koliko bila krizna smatra se uspešnom za srpsku privredu (u poređenju sa privredama u Evropi, a pogotovo u regionu). $\mathrm{Na}$ to ukazuju sledeći pokazatelji: minimalni pad društvenog bruto proizvoda; minimalno otpuštanje radnika; efikasna i efektna državna pomoć privrednim subjektima; pomoć turističkim i hotelskim privrednicima (minimalna isplata zarada); novčana pomoć stanovništvu (posebno penzionerima); minimalna erozija standarda i kupovnem moći stanovništva. Državna pomoć omogućila je firmama da finansiraju obrtni kapital i nadoknade smanjene prihode. Tako je zaustavljen „Cunami“ nesolventnosti, izbegnuta trajna šteta proizvodnim, uslužnim i, delimično, turističkim kapacitetima, kao i masovno otpuštanje radnika. Međutim, pošto pandemija još nije savladana neophodan je veliki oprez tokom čitave 2021 godine naročito u uslužnim-tercijalnim delatnostima izloženim najvećem udaru zdravstvene krize.

Ključne reči: privreda, pandemija, uslužne delatnosti, održiv razvoj, turizam.

\begin{abstract}
This paper explains the negative impacts caused by the emergence of the business crisis as a result of the pandemic. In the general economic crisis, companies and individuals (especially from service and tertiary activities) need help in overcoming the difficulties caused by the long-term recession, but such help has its limits determined by the fiscal deficit and public debt. Therefore, if these borders are crossed, the entire economy is exposed to great risk and macroeconomic instability, which would affect all segments of the economy and society. Of course, this has negative consequences, especially for service activities, especially for tourism. The coronary virus pandemic that has plagued economies around the world has only deepened social inequality. While a number of employees are lucky enough to work from home, millions of workers lose their jobs or risk their health in lower-paid jobs away from their homes. However, 2020, no matter how crisis, is considered successful for the Serbian economy (compared to economies in Europe, and especially in the region). This is indicated by the following indicators: minimal decline in gross domestic product; minimum dismissal of workers; efficient and effective state aid to economic entities; assistance to tourist and hotel businessmen (minimum payment of salaries); financial assistance to the population (especially pensioners); minimal erosion of standards and purchasing eyes of the population. State aid has allowed firms to finance working capital and compensate for reduced revenues. Thus, the "tsunami" of insolvency was stopped, permanent damage to production, service and, partially, tourist capacities was avoided, as well as mass layoffs. However, since the pandemic has not yet been overcome, great caution is necessary throughout 2021, especially in service-tertiary activities exposed to the greatest impact of the health crisis.
\end{abstract}

Keywords: economy, pandemic, service activities, sustainable development, tourism.

\footnotetext{
1orcid.org/0000-0002-5022-2651, e-mail: dragan.zivkovic@majestic.rs

${ }^{2}$ orcid.org/0000-0002-8908-6431, e-mail: pbp954@gmail.com

${ }^{3}$ orcid.org/0000-0002-3652-5488, e-mail: masan.ercegovic@yahoo.com
} 


\section{UVOD / INTRODUCTION}

Pandemija izazvana virusnom infekcijom predstavlja savremenu planetarnu opasnost sa nepovoljno istraženim trendovima u svim sferama ljudske egzistemcije. U uslovima poslovanja koje nameće velika globalna kriza poslovanje odnosno privredni rast i razvoj svih zemalja, a naročito malih privreda, ne zavisi od snage njihovih ekonomija, već, pre svega, od njihove strukture, usmerenosti ka izvozu, prilivu stranih direktnih investicija a posebno od stanja svetskog tržišta i globalnih ekonomskih kretanja. Ublažavanje, odnosno umanjenje ekonomskih posledica pandemije za ekonomsku politiku Srbije biće osnovni zadatak, kao i svake odgovorno vođene ekonomske politike. Najnovija kriza, od 2020 godine, kao i one iz 2008 i 2014 godine, ponovo će zaustaviti, pa i unazaditi razvoj malih i srednjih ekonomija. Kapital, koji se pojavom pandemije počeo povlačiti iz mnogih zemalja u razvoju, predviđa se da će taj proces biti dugoročan i da će se ubrzavati, sa negativnim uticajem na rast i razvoj malih privreda. Makro analitičari smatraju da je kapacitet malih država nedovoljan da bi same mogle oporavljati svoje privrede. Na svetskom nivou, stručna, ekspertska i naučna javnost kao da nisu, na vreme, sagledavali razorne posledice pandemije. U velikom delu 2020 godine brojni državnii, poslovni ljudi, pa čak i globalni mediji nisu dovoljno ozbiljno sagledavali razorne posledice pandemije, onih delatnosti u kojima su neizbežni lični (fizički) kontakti. S druge strane, predviđa se da će se brojnim finansijskim intervencijama sanirati gubici velikih korporacija i banaka, ali da će svi drugi privredni subjekti i stanovništvo doživeti veliki šok. Na primer, turizam samo što nije zamro tokom 2020 godine.

\section{MATERIJALI I METODE / \\ MATERIALS AND METHODS}

$\mathrm{U}$ razmatranju opredeljenog predmeta istraživanja, shodno cilju rada, korišćene su sledeće metode istraživanja: metod analize i sinteze, jer se rad zasniva na ključnim strateškim dokumentima i programima i merama nadležnih organa, u kontroli i suzbijanju krize izazvane pandemijom. Potom, korišćena je relevantna stručna literatura i zvaničnim publikacijama i dokumentima, pa je bilo neophodno izvršiti adekvatnu selekciju, obradu i analizu relevantne teorijske građe i rezultata prethodnih istraživanja u navedenoj oblasti. Zatim je korišćen metod komparacije i analogije, u smislu donošenje mera srpskih institucija i onih u regionu i EU. Bitan je bio i metod deskripcije u smislu opisa stanja i mera u kriznoj situaciji i predviđanja budućih odluka i mera. S obzirom na polaznu hipotezu (težak položaj tercijalnih delatnosti, posebno turizma) prime- njen je i metod verifikacije. U radu se posebna pažnja obraća na analizu poslovanja ukupne privrede i uporedba sa prethodnim poslovanje kao i teške posledice po uslužne delatnosti i turizam sa hotelijerstvom. Kroz primarna i sekundarna istraživanja i kvantitativne i kvalitativne analize identifikovana je društveno-ekonomska situacija u srpskoj privredi i ukazano na mere i programe u revitalizaciji tercijarnih delatnosti, te su iz toga izvučeni i zaključni stavovi. Dakle, svaka kriza na globalnom nivou ostavlja teške ekonomske i društvene posledice po sve zemlje, a pogotovo na one male i zemlje u razvoju. Međutim, upravo one treba što ranije da donose adekvatne mere stabilizacione ekonomske politike. Pri tome je u donošenju i sprovođenju „teških“ mera najbitnija odlučnost, pravovremenost i obuhvatnost seta mera. Sve zemlje ili vlade da bi ublažile urgentne probleme, na strani ponude i tražnje, a posebno da bi spašavala radna mesta i realni sektor privrede, pripremile su i blagovremeno donele, manje ili više, dobre pakete mera. Bitan izlaz je pronađen $u$ povećanom obimu primarne emisije novca, po osnovu različitih kanala, i u fiskalnoj politici - odgađanje raznih vrsta poreskih obaveza svih ili se direktno pomažu vitalni sektori i soijalno ugroženo stanovništvo. Rešenje je nađeno u tome da se iz budžeta i rezervi, odnosno po osnovu spoljnog i unutrašnjeg zaduživanja (npr. kupovinom obveznica većih domaćih preduzeća) i drugim vidovima doštampavanja novca (npr. "novac iz helikoptera") zaštite ne samo postojeća radna mesta i realni sektor, već i široki slojevi stanovništva. Međutim, u Srbiji, brojni eksperti, postavljaju pitanje održivosti tih mera na duži rok. Upozorava se na moguću pojavu visoke inflacije i stagflacije te da tada malo znače mere monetarne i fiskalne politike u podsticanju razvoja (Mihaljica, 2020). S druge strane, grupa eksperata smatra da je nejasna namera o olakšavanju procedura za emitovanje korporativnih obveznica. Plitko finansijsko tržište, srpske firme čije obveznice moraju imati podinvesticioni rejting, upućuju na mogućnost da će ove vrednosne hartije biti tek novi kanal za ulivanje javnog novca u državne firme, odnosno javna preduzeća (kao oblik štampanja novca). Naime, država bi kupovala kompanijske obveznice nekih firmi, kao vid dokapitalizacije, koje bi nastojale da prošire proizvodnju (npr. EPS, Telekom, ErSrbija). Pretpostavlja se da neće država sredstvima iz budžeta otkupljivati obveznice kompanija već da će to obavljati centralna banka, kao što je to slučaj sa Evropskom centralnom bankom u Frankfurtu ili američkim FED-om. Otkupom državnih i korporativnih obveznica reguliše se količina novca u optiaju, u proesu koji predstavlja kvantitativne olakšie. Sve to 
spada u domen vođenja adekvatne monetarne politike. Na primer, infrastrukturna preduzeća koja emituju korporativne obveznice, kao jedan od načina finansiranja, mogu koristiti više modela. Jedan od sistema bi mogao biti da banke kupuju te obveznice, a onda od banaka obveznice da otkupljuje centralna banka. To bi mogao da bude način na koji bi narodna banka Srbije ubacivala primarnu emisiju novca u finansijski sistem preko poslovnih banaka. Međutim, za uspeh takve operacije neophodno je "duboko finansijsko tržište" ranije emitovanih obveznica. Proces kvantitativnih olakšica ima za cilj da osim „upumpavanja novca“ poveća uticaj centralne banke na obaranje kamatnih stopa za srednje i dugorčne obveznice koje nose, u sebi, povećani i dugoročniji nivo rizika. U situacijama kada se dovodi u pitanje likvidnost, kada se referentna kamatna stopa bliži nuli, a bez ekonomske aktivnosti, preduzimaju se nekonvenionalne mere. Mogu se primenjivati kvantitativne olakšice ali i da centralna banka preuzima ovlašćenja tekuće fiskalne politike. Tada centralna banka ne kreira sav novac poslovnim bankama nego i preduzećima i građanima (,helikopterski novac“) te ga prosto deli umesto da se adekvatna podela obavlja iz budžetskih sredstava tj. rezervi. Neki eksperti smatraju da i pored svih opasnosti, do kojih dovodi ovakva monetarna politika, uz normalno korišćenje sopstvenog novca, može se dosta pomoći ekonomiji da prevaziđe krizni period (Šoškić, 2020). Međutim, taj proces može proizvesti dva problema (Arsić, 2020): (1) monetarna ekspanzija (povećana ponuda dinara) mogla bi da utiče na devizni kurs (nagle oscilacije); (2) neopravdano bi bilo da država, u velikoj meri otkupljuje obveznice državnih preduzeća, to bi bilo isto kao njihovo kreditiranje;

Treba imati u vidu i da kod obveznica kompanija određuje kako i na koji način će dug biti strukturisan i koliku će kamatu nositi, umesto kao kod kredita da to određuje banka. Krediti banaka za prevazilaženje problema likvidnosti (poznatiji kao garantna šema) su povoljni za mala i srednja preduzeća i predstavljaju izuzetno ozbiljan odgovor na krizu u kojoj se našao ceo svet, pa i Srbija, koja je to prihvatila. Ukupnom paketu pomoći, tokom 2020 godine, koji je iznosio preko 5 milijardi dolara, banke su doprinele sa oko dve milijarde evra, kroz moratorijum, a još dve milijarde kroz kreditne linije. Pri tome treba imati u vidu da je u Srbiji bankarski sistem visoko kapitalizovan i da poseduje resurse namenjene kreditiranju privrednih subjekata u cilju prevazilaženja opšte ekonomske krize. Globalna pandemija uzrokovala je prelazak na rad na daljinu, trend koji će trajati godinama, a mnogi zaposleni očekuju da će raditi kod kuće bar nekoliko dana u nedelji i nakon završetka zdravstvene krize. Mnogim delatnostima to nije ostavilo negativne posledice, ali za uslužne delatnosti ostavile su ogromne negativane efekte.

Ekonomski eksperti imaju oprečna mišljenja o merama ekonomske politike koja se sprovodi u Srbiji u doba krize izazvane pandemijom (npr. najviše polemike je izazvalo deljenje pomoći stanovništvu, na početku pandemije, u iznosu od 100 evra), ali vrlo je važno da u ovim uslovima nije došlo do slabljenja nacionalne valute, naprotiv kurs dinara ostao je stabilan.

Stručnjaci smatraju da su mere Vlade Srbije, u borbi protiv krize izazvane svetskom pandemijom dale dobre rezultate, naročito na planu zapošljavanja, to jest sprečavanja da se broj nezaposlenih poveća. Posebno je bila važna isplata tri minimalne plate, što je u kombinaciji sa drugim merama, kao što su povoljni krediti za obrtna sredstva, mogućnost da privredni subjekti odlože plaćanja poreza i doprinosa. „Zahvaljujući merama koje je vlada do sada preduzimala i strukturi naše privrede, ima dovoljno razloga da verujemo da će uticaj korona krize biti relativno slabiji kod nas nego u drugim ekonomijama u okruženju“ (Hanić, 2020). Smatra se da strani investitori imaju relativno visok stepen poverenja u stabilno okruženje u Srbiji, povoljnije nego u zemljama regiona. Međutim, da bi se podstakli i domaći investitori i preduzetnici, važno je da država obezbedi dodatne povoljnosti u vidu subvencija i podsticanja rasta i razvoja naročito nedovoljno razvijenih područja, koja često predstavljaju uska grla za brži privredni rast i razvoj Srbije. Zbog saniranja ekonomskih posledica korone, predviđa se porast javnog duga, tako da bi iznosio 29 milijardi evra na kraju 2020 godine, uz nemogućnost zaustavljanja njegovog daljeg rasta bez ozbiljnijih razvojnih i socijalnih posledica (Guzina, 2020). To je zbog toga što je kamatni trošak srpskog javnog duga dvostruko viši od evropskog proseka, i pored dobrih rezultata u otplati skupih dugova i restrukturiranju javnog duga u korist kamatno povoljnijih dugova tokom poslednjih godina. Procenjuje se da će sa rastom duga budžetski trošak, po osnovu kamata, ponovo uveliko premašiti milijardu evra godišnje (Guzina, 2020). Stoga je u narednom periodu najveći prioritet - javne investicije, na nivou od bar pet odsto BDP-a, i to one koje neposredno doprinose ekonomskom aktiviranju demografski i privredno zapuštenih regiona Srbije. Međutim, to zahteva velika, dodatna budžetska sredstva. Naime, bez tih investicija, promene ekonomskog i političkog sistema, kao i kreiranje povoljnog poslovnog ambijenta, nema zadovoljavajućeg rasta BDP. a, i kvalitetnog razvoja. Prosečan rast BDP-a u 
narednim godinama, od najmanje 4 odsto (što je maksimum u kriznim vremenima) neće biti dovoljan na svođenje budžetskog deficita na dva odsto BDP-a. U cilju zaustavljanja potencijalno veoma opasnog daljeg rasta javnog duga i počeo da se smanjuje u narednim godinama, neophodno je oštro smanjenje deficita već u 2021 godini. Planirani deficit od oko 2 odsto BDP-a jer bi se takvim deficitom vratila narušena fiskalna stabilnost. Međutim, dostizanje deficita od oko 2 odsto u 2021 godini, neće biti nimalo lako jer se u 2021 godinu ulazi sa strukturnim slbostima javnih finansija i povećanim obavezama budžeta (snažni rast javnog duga podiže kamate). Najvažnije sidro za fiskalnu stabilnost u 2021 godini jeste čvrsta kontrola plata u javnom sektoru. Stoga, izvor za smanjenje deficita u 2021 godini ne bi trebalo da bude povećanje poreza jer bi to negativno uticalo na privredni rast. $\mathrm{Na}$ rashodnoj strani budžeta, takođe, nema mnogo raspoloživih mera koje bi mogle stabilizovati javne finansije. Kada se isključe penzije, čije je povećanje u 2021 već definisano, kao i javne investicije u infrastrukturu koje iz ekonomskih razloga ne bi trebalo nikako da se smanjuju, kao najvažnije sidro fiskalne politike preostaju plate zaposlenih u javnom sektoru, koje moraju da se čvrsto kontrolišu (Živković, Ercegović, 2019). U slučaju dužeg trajanja pandemije, koja bi zahvatila celu 2021 i 2022 godinu predlog pomoći privrednim subjektima i stanovništvu mogao bi obuhvatati sledeće mere u stabilizacionom programu za ublažavanje posledica krize: 1) zabrana otpuštanja radnika za sve poslodavce kojima je država pokrila 60 odsto minimalne zarade (produžetak mere); 2) prihvatiti zahtev Unije poslodavaca i PKS da se PDV u sektoru hotelijerstva i ugostiteljstva (za hranu i piće) smanji na 10 odsto; 3) odlaganje plaćanja poreza i doprinosa na zarade ili da se one u sektoru malih i srednjih preduzeća delimično otpišu; 4) obustavljanje uvođenja novih taksa i dažbina na državnom i lokalnom nivou; 5) nastavljanje garantne šeme za podršku likvidnosti i investiciona ulaganja za mala i srednja preduzeća; 6) nadoknada do punog iznosa zarade zaposlenog, a koja iznosi najviše do 50 odsto zarade u slučaju da, zbog smanjenog obima posla, poslodavac nema potrebu za angažovanjem zaposlenog na puno radno vreme.

Unija poslodavaca predlaže (pošto je dosta sredstava utrošeno za pomoć u 2020 godini) da se za naredni period napravi selekcija, te da se pomogne onom delu privrede Srbije koji je najviše trpeo posledice krize izazvane pandemijom i gde postoji opassnost da najveći broj firmi prestane da posluje ili otpusti veći broj zaposlenih. Potrebno je da se iznađe ravnoteža između zdravlja ljudi i potrebe da privreda ostane na neki način aktivna (preraspodela želja i mogućnosti). U svakom slučaju pomoć privredi dovelo bi do umanjenja nekih drugih rashoda odnosno investicija (npr. Izgradnja metroa ili nacionalnog stadiona). Turizam je jedna od najvećih i najbrže rastućih industrija u svetu. Ekonomski napredak doveo je do rasta raspoloživog dohotka koji je, zajedno sa savremenim uslovima rada, rezultirao povećanje plaćenog vremena za odmor ljudi u ulogu rekreativaca i turista. Zato se danas ulaganje u turizam često smatra održivim sredstvom za podizanje ekonomske aktivnosti zelje i regiona (Jerkić i dr., 2019). Ekonomisti smatraju da bi se u narednom periodu mogla izdvajati sredstva kao jednokratna pomoć određenim sektorima privrede (kao turizam i ugostiteljstvo), ali ne i kao sistemska i dugoročna rešenja.

\section{REZULTATI I DISKUSIJA / RESULTS AND DISCUSSION}

Uticaj pandemije (sa permanentnom ekspanzijom, dramatičnom eskalacijom i katrastofalnim reperkusijama) tokom poslednjih godinu dana imperativno je zahtevao sveobuhvatni pristup $u$ obuzdavanju te ogromne pošasti. U slučaju dugotrajnijeg trajanja sveobuhvatne, globalne krize dosadašnji pozitivan trend osnovnih ekonomskih indikatora može biti usporen ili čak negativan, a to su: rast BDP-a, suficit budžeta, visoke investicije, niži javni dug i stabilnost domaće valute. I pored svih analitičkih aparata koje se mogu primeniti $u$ istraživanjima smatra se da je privredna kretanja, u trećoj deceniji dvadesetprvog veka, teško praviti, a glavni uzrok promena na tom planu su neizvesnosti oko pandemije i njenih posledica. Smatra se, da će Srbija, zbog strukture privrede, imati nešto manji privredni pad, koji se u narednim godinama moguće nadoknaditi. Mnoge privrdne grane odnosno aktivnosti imaće i dalje ograničenja, mali biznis, usluge, turizam, saobraćaj. Mora se voditi računa da ne bude velikog budžetskog deficita i povećanja javnog duga. Sprovođenje ekonomskih mera treba biti obazrivo jer pandemija traje i u 2021 godini. Dosadašnje vreme dvadesetprvog veka protiče $u$ znaku već treće globalne i opšte društvene krize. Za razliku od prethodnih finansijskih i opšteekonomskih ova je inicirana globalnim zdravstenim problemima odnosno pandemijom. Pojava pandemije, početkom 2020 godine već u toj godini ima vrlo razorne socijalne i ekonomske posledice.

Ekonomske krize malih zemalja, po pravilu, počinju kao finansijske i valutne a potom prerastaju u dužničke i bankarske. Potom, naglo se smanjuju strane direktne investicije odnosno unos kapitala i/ili povlače već uneti kapital (Katić, 2020). Proces 
da se kapital povlači iz zemalja u razvoju dobijaće svoje ubrzanje, a slabe ekonomije doživljavaće sve nove i nove šokove, jer je njihov kapacitet za saniranje posledica koje donosi kriza, nedovoljan. S druge strane, moćne i razvijene zemlje, koje hiljadama milijardi subvencionišu svoje kompanije (koristeći naglo širenje pandemije kao izgovor) žestoko narušavaju pravila globalne tržišne utakmice i sva ona pravila koje su same postavile $u$ globalnim tržišnim relacijama. Osim toga, predviđa se, da će razvijene države i međunarodne finansijske organizacije (pre svih MMF) ponuditi obilniju pomoć u vidu kredita, dovodeći zemlje u razvoju pred vrata dužničke krize. Zatim, predviđa se, kad prođe ova kriza, nastaviće se privredni život po iscrpljujućem šablonu koji savremeni kapitalizam nameće: efikasnost, profit, konkurenija. Stoga, male zemlje ne treba da gledaju na loše strane globalnih odnosa i proesa nego da vide svoje mogućnosti i razvojnu šansu.

Globalizacija utiče na veliki broj aspekata ekonomskih performansi domaćih i međunrodnih preduzeća i drugih poslovnih subjekata. U najvećem broju istraživanja smatra se da su ključne karakteristike uspešnih preduzetnika sledeće (Petrović, Pavlović, 2018): inovativnost, izražena želja za uspehom, podizanje nivoa samopouzdanja, samokontrola, samostalnost, prihvatanje rizika i tolerancija na neizvesnost. U narednom periodu problem likvidnosti, sa aspekta poslovanja malih i srednjih preduzeća, doći će u prvi plan, stoga garantna šema koju obilato nude banke, smatra se kao veoma povoljno rešenje, jer postoji i grejs period (sa niskom kamatnom stopom) a koji je vrlo bitan za preduzeća u situacijama kad imaju smanjene prihode, odnosno nedovoljnu likvidnost. Na globalnom nivou države koje su oslonjene na turizam, ili one koje su veliki izvoznici (bilo sirovina bilo industrijskih proizvoda) ostvariće najveći, ubrzani pad svog BDP-a (Katić, 2020). Kriza će više uticati na investicije nego na izvoz i zaposlenost, a takođe više će varivati profit nego poslovni prihod. $U$ tim okvirima, finansijski sektor će biti manje pogođen nego realni sektor, a rezultati ankete (Savet stranih investitora sproveo među trećinom svojih članova, jun 2020) ukazuju da se uklapaju u tekuće kretanje BDP-a, praćen tokom 2020 godine za vreme trajanja pandemije (Bela knjiga, 2020). Uglavnom su mere vlade, za vreme trajanja pandemije i $u$ borbi protiv recesije, bile prevashodno fiskalne i monetarne prirode. Ne dovodeći u pitanje pozitivno dejstvo ovih mera smatra se da je većina raspoloživosti fiskalnog prostora već iskorišćeno. Učinak je bio povoljan, što se vidi na malom padu BDP-a, ali je imao i značajne fiskalne troškove. Kako je eko- nomija u recesiji, a javni dug u naglom porastom, prostor za buduće podsticajne mere jeste ograničen. Potrebne su, stoga, dalje institucionalne reforme kako bi se ekonomija vratila održivom rastu i osigurala radna mesta. U tom smislu unapređenje poslovnog ambijenta predstavlja veliku potrebu. $U$ poreskoj politici najveći problemi se ne nalaze $u$ propisima i institucijama, a nego u fiskalnoj politici, koja se dosledno ne primenjuje. Prema brojnim analitičarima energetski sektor jedan od pet najbitnijih stubova i prioriteta privrednog razvoja zahteva brze promene. Predlaže se da regulacija cena električne energije bude napuštena (uz zaštitu osetljivih kupaca), što bi omogućilo nova ulaganja u modernizaciju i revitaalizaciju proizvodnje uglja i električne energije, ali sa ugrdnjom filtera zbog velikog aerozagađenja. U oblasti telekomunikacije važan momenat, u uslovima vanrednog stanja bio je nagli skok domaćeg saobraćaja, koji je prevazilazio postojeće kapacitete operatora, usled čega je jedan od glavnih prioriteta bilo značajno investiranje u mrežu da bi se u što kraćem roku obezbedilo proširenje kapaciteta. $U$ isto vreme, došlo je do drastičnog opadanja roming saobraćaja usled ograničenja kretanja ljudi van teritorije nacionalnih granica u čitavom svetu, što je imalo za posledicu smanjenja prihoda. Sa aspekta daljeg usmeravanja privrednog razvoj za Srbiju je vrlo bitno mišljenja i preporuke Saveta stranih investitora, a to su između ostalog: primena Zakona o planiranju i izgradnji, primena objedinjene procedure za pribavljanje građevinskih dokumenata, legalizacija postojećih objekata u skladu sa novim propisima, konverzija prava korišćenja na građevinskom zemljištu u pravo svojine i primena propisa o katastru i katastarskom postupku. Kriza će ostaviti ozbiljne i teške posledice po svim zemljama, a posebno na zemlje u razvoju i nedovoljno jake i otporne ekonomije. Posebno će biti pogođene one ekonomije u kojima turizam i usluge čine bitnu privrednu strukturu savelikim učešćem u stvaranju društvenog proizvoda i zapošljavanja stanovništva.

\section{ZAKLJUČAK / CONCLUSION}

Analize pokazuju da je privreda Srbije relativno dobro podnela udar na regularno poslovanje tokom 2020 godine. Pandemija je ostavila manje „ožiljaka“ na našu privredu nego li na privrede gotovo svih evropskih zemalja. Privreda Srbije za razliku i od svih zemalja regiona, imala je i umereniji rast zaduženosti u 2020 godini. Učešće korporativnog duga u BDP-u je krajem prošle godine neznatno uvećano, u poređenju sa prethodnom godinom. Prema podacima NBS dug privrede je i dalje za gotovo četvrtinu niži u odnosu na rekordnu zaduženost od 
33,5 odsto iz 2012 godine. On obuhvata ukupna potraživanja domaćeg bankarskog sektora prema javnim preduzećima i privrednim društvima (u koje se računaju i korporativne obveznice kao novi vid finansiranja privrede koji je otpočeo u septembru 2020 godine), a takođe mnogo na nivo dugova ne utiču ni prekogranična zaduženja preduzeća. Raspoloživi podaci ukazuju da je Srbija i tokom teške 2020 godine očuvala visoku efikasnost funkcionisanja finansijskog tržišta, kreditnu aktivnost i podršku privredi. Bankarski sektor je adekvatno kapitalizovan i otporan na rast kreditnog rizika usled i dalje nepovoljnih makroekonomskih kretanja koja su posledica pandemije. $O$ tome svedoči i učešće problematičnih kredita u ukupnim kreditima koji se smanjio na najniži nivo, $S$ druge strane, $u$ pogledu ulaganja u tercijalni sektor, nema dileme da će jedan deo privrednih subjekata odložiti ili otkazati neke planirane kapitalne izdatke. To su vrlo osetljive delatnosti koje su nadprosečno pogođene pandemijom, čija je realizacija otežana, koje su bez rezervi i čija se bilansna neravnoteža ne može lako zatvoriti.

\section{LITERATURA / REFERENCES}

[1] Arsić, M., (2020), Korporativne obveznice su za dobra vremena ne za krizu, Danas, Beograd, 06.04.2020, str.3.

[2] Bela knjiga 2020, (2020), Politika, Beograd, 19.11.2020, str.1-3.
[3] Guzina, V., (2020), Ekonomske posledice korone, Politika, Beograd, 27.04.2020, str.18.

[4] Hanić, H., (2020), Beogradska bankarska akademija, Politika, Beograd, 22.11.2020.

[5] Jerkić, T., Okanović, A., Vukadinović, S., (2019), Značaj ruralnog turizma za privlačenje kineskih turista u Srbiju, Ecologica, Vol. 26, No. 96, str. 469-474.

[6] Katić, N., (2020), Ekonomske projekcije i gledanje u pasulj, Politika, Beograd, 22.04. 2020, str.11.

[7] Mihaljica, M., (2020), Spasavanje obolelih, ali i ekonomije, Politika, Beograd, 01.04.2020.

[8] Petrović, P., Pavlović, Đ., (2018), Preduzetništvo traži kredite, Ekobiz, Zbornik, Bijeljina, BiH, jun, 2018, str.23.

[9] Petrović, P., (2019), Srbija u novom društvenoekonomskom sistemu, Institut za međunarodnu politiku i privredu, Beograd.

[10] Šoškić D., (2020), Korporativne obveznice su za dobra vremena, ne za krizu, Danas, Beograd, 06.04. 2020 str.3.

[11] Živković, D., Ercegović, M., (2020), Način funkcionisanja malih i srednjih preduzeća u hotelijerstvu i eko-turizmu, Ecologica, Vol. 27, No 97, str. 75-81. 